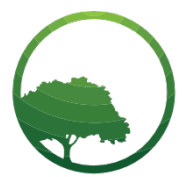

Research in Business \& Social Science

IJRBS VOL 8 NO 5 ISSN: 2147-4478

\title{
Relationship between corruption and capital flight in Kenya: 1998- 2018
}

\author{
Mercy W. Mwangi ${ }^{a *}$, Amos G. Njuguna ${ }^{b}$, George O. Achoki ${ }^{c}$ \\ ${ }^{a, b, c}$ Chandaria School of Business, United States International University - Africa, Nairobi, Kenya
}

Crossref

\begin{tabular}{l} 
A R T I C L E IN \\
\hline Article history: \\
Received 14 July 19 \\
Received in revs. fo \\
Accepted 12 Augus \\
\hline Keywords: \\
Capital Flight \\
Corruption \\
Exchange Rate \\
GDP Growth Rate \\
JEL Classification: \\
D72 \\
D73 \\
F31 \\
O10
\end{tabular}

\author{
A B S T R A C T
}

The study established the relationship between corruption and capital flight in Kenya over the period 1998 to 2018. Quarterly time series data for calculation of capital flight and for GDP growth rate and exchange rates were collected from the Central Bank of Kenya and Kenya National Bureau of Statistics. Corruption perception index data was collected from the Transparency International website. Two Autoregressive Distributed-lagged models were fitted. Regression coefficients for corruption were -0.114 and 0.066 in the short run and -0.501 in the long run and the palues were 0.523 and 0.691 and 0.558 respectively, indicating no significant relationship. Regression results showed a coefficient of 0.01 and 0.003 for the Gross Domestic Product growth rate in the short run, and 0.049 in the long run. The $p$ values were $0.670,0.855$ and 0.578 respectively denoting no significant relationship. Regression results showed a coefficient of 0.002 and 0.003 for the exchange rate in the short run, 0.43 for the exchange rate in the long run. The p values were 0.891 and 0.584 and 0.095 respectively indicating that a one \% increase in the exchange rate would lead to a $0.043 \%$ increase in capital flight in the long run. Regression results of lagged capital flight on capital flight showed a coefficient of 0.904 . The p-value was 0.000 meaning that a one \% increase in lagged capital flight would lead to a $0.904 \%$ increase in capital flight. The study recommended that the government devises policies that would prevent further capital flight and generate capital flight reversal.

\section{Introduction}

Capital flight has negative impact on economic growth, macroeconomic stability, income distribution and welfare and undermines the effectiveness of poverty reduction policies (Moulemvo, 2016; Nkurunziza, 2012, 2015). Fighting capital flight is therefore an important driver of development for poor countries like Kenya whose GDP growth rate has been deteriorating since the 1970s (Kimenyi, Mwega and Ndung'u, 2016). According to Letete (2015) Kenya has faced high corruption levels for the past four decades of the post-independence. Several incidences of grand corruption scandals concerning the transfer of illicit money by the reigning political elites from the 1970 s to the 21 st century have been reported. They are claimed to have exhausted the already inadequate public resources and led to sub-optimal investment, and increasing debt levels, as well as weakened tax moral responsibility between public and the government. They have also added to the growing horizontal disparity in the country (Letete, 2015).

Kenya is also on the top 20 list of African states with capital flight (Hope, 2014). In year 2015 capital flight stock in Kenya was US\$29.4 compared to debt stock of US\$ 19.1.4; it was 30\% of GDP (Ndikumana and Boyce, 2018). Despite the serious capital flight problem in Kenya, few country-specific studies have investigated capital flight. The few that exist include (Ng'eno, 2000); Kipyegon (2004); Moeva (2007), Mudida (2011); Letete (2015); Muchai and Muchai (2016); Gachoki and Nyang'oro (2016); Letete and Sarr (2017) and recently Barasa (2018). They have examined portfolio diversification motives, political and macroeconomic uncertainty, fiscal deficits, and devaluation of local currencies as some of the factors causing capital flight.

\footnotetext{
* Corresponding author. Tel: +254722832987 ORCID ID: 0000-0002-0205-1405
} Peer review under responsibility of Bussecon International Academy. (C) 2019 Bussecon International. Hosting by SSBFNET- Center for Strategic Studies in Business \& Finance. All rights reserved. https://doi.org/10.20525/ijrbs.v8i5.318 
None of these studies have examined how corruption influences capital flight in Kenya, though Kenya is still classified as one of the most corrupt countries in the world (Hope, 2014; TI, 2016). Moeva (2007) did not investigate corruption in their study due to lack of data.This study intended to contribute to the empirical literature by bringing in corruption as an important institutional governance factor and examined its relationship with capital flight in Kenya. The study attempted to address the following question; Has corruption in the Kenyan economy intensified the intensity of capital flight? The study added to the other studies that attempted to understand capital flight and corruption from Africa. These included those by Yalta and Yalta (2012); Ndikumana and Boyce (2008, 2011); Ali and Walters (2011); Fofack and Ndikumana (2010); Cerra et al. (2008). In order to avoid variable omission bias, the study controlled for GDP growth rate and exchange rate. This study contributes to the literature on capital flight from Kenya by filling this gap by bringing in corruption as one of the variables in the study. Corruption was measured by the annual corruption perception index (CPI) provided by Transparency International (TI). The objectives of the study were to determine the relationships between corruption, GDP growth rate and exchange rate and capital flight. The study tested the following hypotheses

H1 There is no positive significant relationship between corruption and capital flight.

H2 There is no significant relationship between GDP growth rate and capital flight.

H3 There is no positive significant relationship between real exchange rate and capital flight.

The rest of the paper is outlined as follows. The next section, section two presents a review of the key theories forming the foundation of the study and the conceptual framework. An empirical review of studies conducted on the topic, was reviewed based on the specific objectives. Section three presented the methods used in the study. In section four, the empirical data and analysis and results and discussions were reported while section five gives the conclusions of the study.

\section{Literature Review}

\section{Theoretical review}

The study is underpinned under two theories, political economy theory and theory of capital flight.

\section{Political economy theory}

Its origin can be found in the work of Adam Smith's Wealth of Nations, of David Ricardo and Karl Marx (Smith, 1976; Ricardo, 1951; Marx, 1961). According to the political economy literature, capital flight is the result of rent extraction by unconstrained corrupt practices of political rulers and their elite groups. Alesina and Tabellini (1989) noted that the rulers and elites knew that even if they accumulated foreign debt, they would not inherit the burden, which would be placed on future (possibly rival) regimes. Capital flight arises through the desire to hide illegally accumulated wealth abroad and not necessarily due to interest rate differentials between countries or macroeconomic policy distortions as postulated under the portfolio choice theory approach (Kar and CartwrightSmith, 2008, 2010). Thus, capital flight from African countries can be understood to be a result of corruption by African leaders and the politically connected (Heggstad and Fjeldstad, 2010)

\section{Theory of capital flight}

Latest economic literature is not continuously clear as to what institutes capital flight, and the elusiveness of the term both hampers the development of a theory of capital flight. The theory of capital flight is therefore still evolving (Abalkin and Whalley, 2002). There are two alternative approaches in literature to identify the capital flight phenomenon: motivational and normative (Abalkin and Whalley, 2002). The motivational approach concentrates attention on considering the reasons of economic agents for exporting capital. The motivational approach was originated by Kindelberger (1937) and is rooted in political and economic uncertainty of the domestic economy. The normative approach to measuring capital flight focused on the macroeconomic consequences of the capital flight, i.e. the negative effect on the country's economic development.

Ndiaye (2014), Ndikumana and Boyce (2011) and Ajayi, (2007) notes that the theory of capital flight proposes that the occurrence is motivated by private players due to macroeconomic volatility, political and institutional uncertainty, less developed financial system, and greater rate of return variances abroad. Public authorities also contribute to capital flight under circumstances of poor governance and bad institutional quality (Ndikumana and Boyce, 2003; Le and Rishi, 2006; Cerra et al, 2008 and Ndiaye, 2011). In such a situation, corrupt public authorities take advantage of their favourable position to accumulate a personal fortune abroad (Boyce and Ndikumana, 2001). As these resources held overseas are local public resources, capital flight operated by public authorities leads to a decline in public resources, thereby encouraging a fall in public investment and, therefore, a decline in growth. According to the theory, under situations of poor governance and bad institutional quality corrupt public authorities take advantage to accumulate personal wealth abroad (Onodugo, Kalu, Anowor and Ukweni, 2014).

\section{Conceptual Framework}

Figure 1 below shows the relationship between corruption; exchange rate and GDP growth rate, the control variables of the study and their relationship with capital flight. 


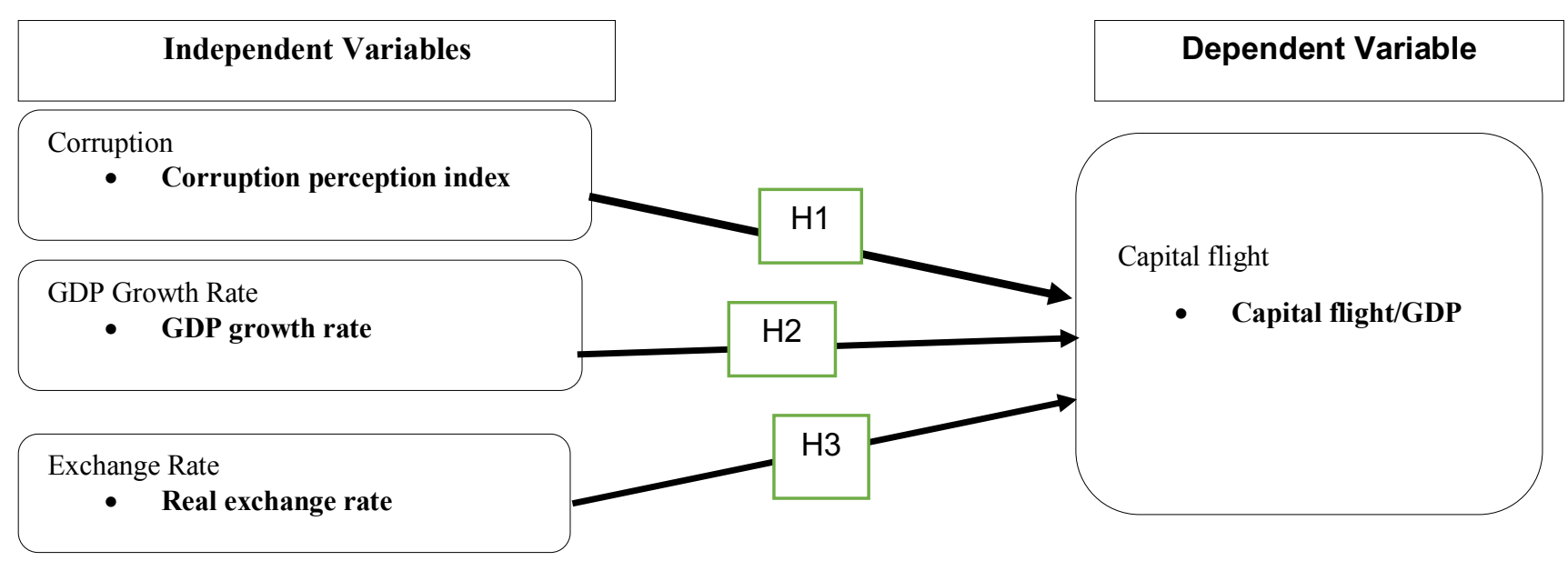

Figure 1: Conceptual Framework

Source: Authors' Compilation

\section{Empirical Review}

\section{Capital flight}

Every year over US\$ one trillion vanishes without a trace from developing countries, ending up in tax shelters or rich nations. Raymond Baker, High-ranking Fellow at the US Centre for International Policy, has described this as the ugliest stage in worldwide economic affairs since slavery (Waris and Fröberg, 2011). The phenomenon of capital flight can be traced back to the 17th century in Europe and to the 20th century in USA (Wujung and Mbella, 2016). Up to and until the early 1990s, it was treated as an entirely Latin America problem. Focus on capital flight on the African continent started in the latter part of the 1990s (Kindleberger, 1987) Mpenya, Metseyem and Epo (2016) records that the issue of capital flight, which was the focus of attention for some economists in the 1980s (Erbe, 1985; and Deppler and Williamson, 1987), has drawn increased interest ever since the early part of years 2000 s. This revitalized attentiveness was because of works of Boyce and Ndikumana (2001), Ndikumana and Boyce (2003) and Collier, Hoeffler and Pattillo (2004), which showed that since the 1970s, substantial amounts of funds fled from Africa. The interest arose due to, among other reasons; the potential positive role that external assets stored away in foreign economies can play, if left in the domestic economy. For instance, these moneys could have been invested domestically to fuel economic development and reduce unemployment (Kipyegon, 2004).

Capital flight is a complex phenomenon that is difficult to define and has is no commonly accepted definition (Olawale and Ifedayo, 2015). Due to this there is no theoretical standard measure of capital flight leading to different methods of its computation and consequently to divergent estimates (Hermes, Lensink and Murinde, 2002). The study adopted the definition of capital flight by Epstein (2005) who defined capital flight as the transfer of assets overseas in order to lessen loss of principal, loss of return, or loss of control over one's economic wealth due to government-sanctioned activities.Developing countries whose financial status are often not strong enough to endure huge amount of capital flight are mostly affected (Liew, 2016). Kar and Spanjers (2015) reported that approx. US\$ one trillion in capital flight was relocated out of developing states in 2012. This was ten times the sum of Oversees Development Aid (ODA) received that year. It was also four times higher than the US\$40-60 billion required every year to meet the Sustainable Development Goals (SDGs) by 2030 (Waris and Fröberg, 2011). Capital flight from Africa has been denoted as an illustration of the Lucas paradox (Lucas, 1990) (Ndikumana and Sarr, 2016). Ndikumana and Boyce (2018) gives evidence that African countries lose more through capital flight than they receive in the form of aid or foreign private investment. When capital flight is scaled as a proportion of GDP, Sub-Sahara Africa tops the list, with capital flight averaging $6.1 \%$ of the region's GDP.Ndikumana and Boyce (2018) estimated that in 2015, the East African Community had capital flight stocks of USD 124.6 billion, of which Uganda accounted for USD 23.3 billion, Kenya USD 29.4 billion, Tanzania USD 41.2 billion, Burundi USD 5.8 billion and Rwanda USD 24.9 billion on average. Expressed as ratio to GDP, capital flight was 30\% in Kenya, 63\% in Tanzania, $83.7 \%$ in Uganda, $213.7 \%$ in Rwanda and $181.8 \%$. Between the year 2003 and 2012 cumulative capital flight from Kenya was US\$860 million (Kar and Spanjers (2014). Ironically, over the same period, the net ODA received by Kenya amounted to US\$1106 million (Republic of Kenya, 2013). In 2015, Ndikumana and Boyce (2018) reported that capital flight in Kenya was 30\% of the GDP.

\section{Corruption and capital flight}

Domfeh et al. (2018) examined capital flight and institutional governance in SSA: the role of corruption in thirty-two (32) countries in SSA for period 2000-2012. Result of the empirical estimation proved that corruption had a positive and statistically significant influence on capital flight. 
Orkoh, Claassen and Blaauw (2018) examined the influence of corruption control and political constancy on capital flight in SSA. Results indicated that at $1 \%$ level of significance, $1 \%$ increase in the corruption control score of a country reduces capital flight by about $1.5 \%$.

Abotsi (2018) conducted a study established on secondary data (panel) obtained from the GFI, World Development Indicators and WGI. The study found that corruption had a significant positive effect on capital flight.

Trabelsi, Kharrat and Feki (2018) analysed the root causes of Capital flight in Tunisia using annual data between 1984 and 2014. The results indicated that the major incentive for capital flight was corruption.

\section{GDP growth rate and capital flight}

Salandy and Henry (2018) examined capital flight in Trinidad and Tobago during the pre and post financial liberalization. The results indicated GDP growth rate and capital flight had a positive and significant relationship.

Forson et al. (2017) investigated capital flight in Ghana using the ARDL estimation technique. The results showed that capital flight and GDP growth rate had long run and short-run negative relationship.

Uddin, Yousuf and Islam (2017) examined the factors that caused capital flight from Bangladesh for the period 1993 to 2013 . The findings were that GDP growth rate had an insignificant relationship with capital flight in two of the models.

Pradhan and Gourishankar (2017) examined the causes of capital flight in India for the period 1990 to 2012. The empirical result showed that capital flight and GDP growth rate had a positive and significant relationship.

Bekele (2017) examined the determinant of capital flight from nine Eastern Africa countries for the period 2006 - 2015. GDP growth had negative effect on capital flight at 5\% level of significance in the Eastern African countries. A 1\% change in economic growth was associated with a $0.95 \%$ change in capital flight.

\section{Real exchange rate and capital flight}

Pradhan and Gourishankar (2017) examined the determinants of capital flight in India for the period 1990 to 2012. The empirical results suggested that exchange rate influenced capital flight negatively and significantly.

Cheung et al. (2016) examined China's capital flight pre- and post-crisis experiences. The findings indicated that capital flight was influenced positively by exchange rate variability.

Ahmad and Sahto (2016) studied the relationship between capital flight in Pakistan and its determinants, which included exchange rate. The results of the study indicated that there existed a positive relationship between capital flight and exchange rate in the long run.

Investigating if a long-run relationship exists between real exchange rate and capital flight in Nigeria, Egbe (2015) used quarterly time series data for the period 1981 to 2009. The results showed that capital flight and real exchange rate have no significant relationship.

\section{Research and Methodology}

\section{Data collection and analysis}

The study employed ARDL (Autoregressive Distributed Lag Model) procedure to analyse the data and answer the research question. The intention of choosing ARDL was because it was more appropriate for the sample due to particular reasons such as, small number of observations and mix of I (0) and I (1) variables in the sample. Secondary data collection sheet was used to collect quarterly time series data for calculation of capital flight and for GDP growth rate, real exchange rates from the central bank of Kenya (CBK) and Kenya national bureau of statistics (KNBS). CPI data was collected from the TI website.

Secondary quarterly time series data was analyzed using STATA 13. Tests carried out before fitting the models included tests for multicollinearity, optimal number of lags and stationary. Upon estimation of ARDL model, post estimation diagnostic tests were carried out to determine the fitness of the models fitted. They included; Model fitness test, Multicollinearity, Heteroschedasticity, Autocorrelation Test and Test for cointegration - Bound test

\section{Model specification for capital flight and estimation technique}

The study used quarterly time series data for the period Q1 1998- Q1 2018 obtained from the CBK and KNBS. The study used an estimation technique developed by World Bank- residual method in order to generate data for capital flight as follow (World Bank, 1985):

$K F_{i}=\left(\Delta D B_{i t}+N F D_{i t}\right)-\left(C A_{i t}+\Delta F R_{i t}\right)$ 
Where: $\mathrm{KF}=$ capital flight,

$\Delta \mathrm{DB}=$ change in total debt outstanding,

$\mathrm{NFDI}=$ net foreign direct investment,

$\mathrm{CA}=$ current account balance,

In addition, $\Delta \mathrm{FR}=$ change in foreign reserve.

The study examined the relationship between CPI the independent variable; real exchange rate and GDP growth rate which were the control variables and capital flight in Kenya.

The specification of the capital flight econometric model was supported by the studies conducted by Geda and Yimer (2016), Forson et al. (2017), Hasnul and Masih (2016), Alam and Quazi (2004), Gusarova (2009), and Liew et al. (2010). The final econometric model of capital flight, therefore, was presented below:

$K F_{t}=\beta_{0}+\beta_{1} F X+\beta_{2} G D P+\beta_{3} C_{t}+\varepsilon_{t}$

Where $\mathrm{KF}=$ Capital Flight capital flight expressed as a percentage of GDP in time $\mathrm{t}$

$\mathrm{FX}=$ Real Exchange Rate in time $\mathrm{t}$

$\mathrm{GDP}=\mathrm{GDP}$ growth rate in time $\mathrm{t}$

$\mathrm{C}=$ Corruption measure as $\mathrm{CPI}$,

In addition, $\varepsilon=$ the error term.

Whereas $\beta, \beta 1, \beta 2, \beta 3$ and $\beta 4$ are partial regression coefficients of independent variables which can through their signs, determine the direction of the relationship between the independent variable and the dependent variable.

\section{Findings and Implications}

\section{Empirical Data and Analysis}

\section{Descriptive Statistics of variables}

Table 1 presents the variables descriptive statistics. Capital flight for the period under review ranged between -0.9874 to 0.3627 with an average value of -0.4147 and a standard deviation of 0.3073 . CPI had a minimum index of 1.9 index against a maximum index of 2.7 index with a mean index of 2.3 and a standard deviation of 0.3 . GDP growth rate ranged between $-2.500 \%$ to $8.30 \%$ with a mean value of 4.4160 and a standard deviation 2.2327. Exchange rate measured by the rate between Kenyan shilling and US dollar ranged between 62.65 and 103.5 with a mean value of 82.03 and a standard deviation 10 .

Table 1: Descriptive Statistics of capital flight, CPI, GDP growth rate and exchange rate

\begin{tabular}{lllll}
\hline & Capital Flight & CPI & GDP growth rate & Exchange Rate \\
\hline Mean & -0.4147 & 2.3 & 4.416 & 82.03 \\
\hline $\mathbf{N}$ & 81 & 81 & 81 & 81 \\
\hline Sd & 0.3073 & 0.3 & 2.233 & 10.21 \\
\hline Min & -0.9874 & 1.9 & -2.500 & 62.65 \\
\hline Max & 0.3627 & 2.7 & 8.300 & 103.50 \\
\hline Skewness & 0.7344 & 0.4 & -0.870 & 0.79 \\
\hline Kurtosis & 3.0742 & 1.7 & 3.506 & 2.9
\end{tabular}

Source: Authors

The normality and the distribution of the variables analysis results are also presented in Table 1. They reveal that capital flight, GDP growth rate and Exchange rate were normally distributed with kurtosis value of 3.0742, 3.5063 and 2.9160 respectively which were close to three. From statistics, the kurtosis value of a normally distributed variable is always equal to 3.0. CPI was non-normally distributed with a kurtosis value of 1.7000. On the distribution of the variables as measured by the skewness of the variables, capital flight CPI and exchange rate were positively skewed meaning that majority of its observations lay on the right of the average value. The supported by figure 1 that gave the $\mathrm{K}$ - density of capital flight, figure 2 that gave the $\mathrm{k}$ - density of all the CPI and figure 4 that give the $\mathrm{k}$ - density of Exchange Rate respectively. On the distribution of the variables as measured by the skewness of the variables, the summary statistics reveal that the GDP growth rate was skewed to the left implying that majority of the observations lay to the 
left side of the average value. The conclusion made regarding the distribution of the variables as measured by the skewness and kurtosis values was supported by figure 3 that give the $\mathrm{k}$ - density of GDP growth rate.

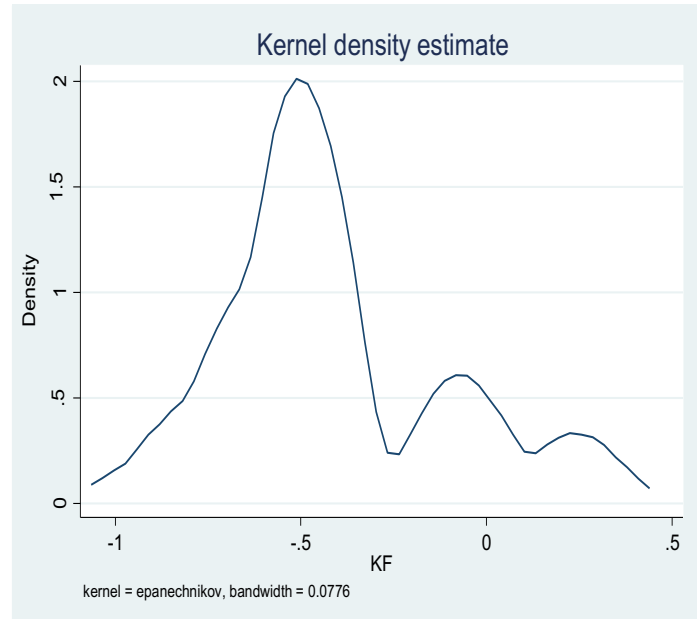

Figure 1: k - Density of Capital Flight

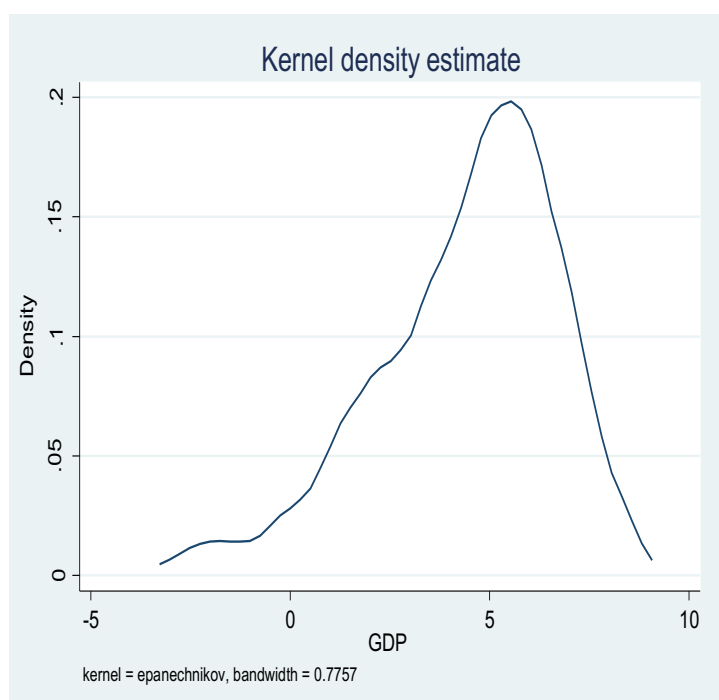

Figure 3: k - Density of GDP growth rate

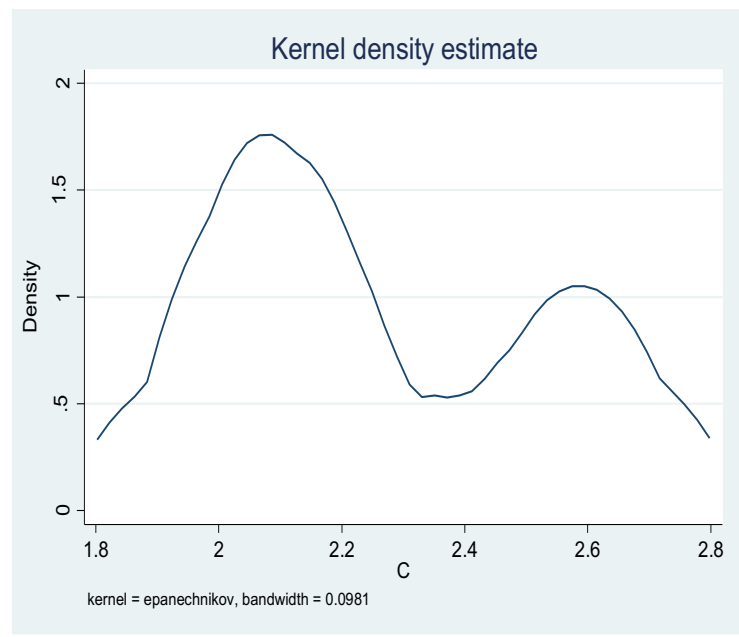

Figure 2: $\mathrm{k}$ - Density of CPI

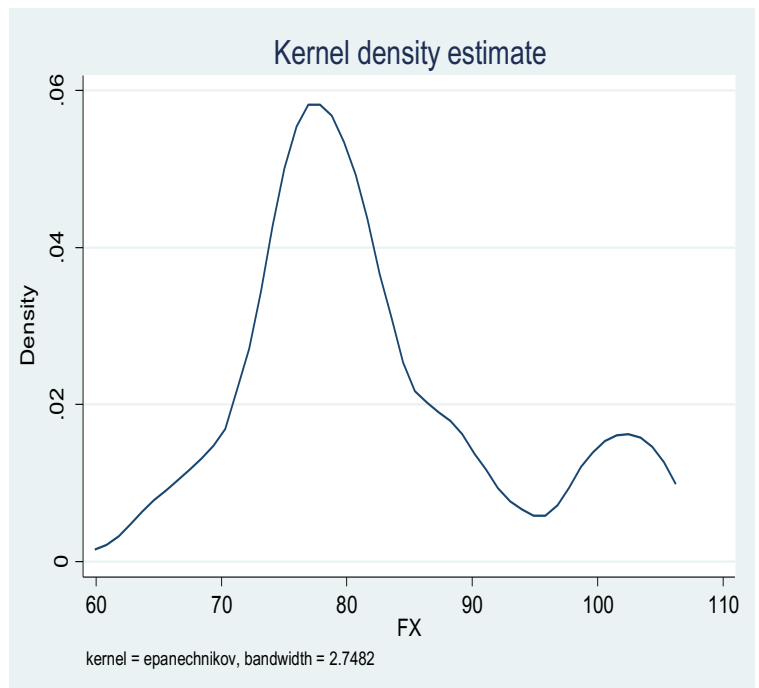

Figure 4: k - Density of Exchange Rate

\section{Trend Analysis of the Variables}

Figure 5 shows the trend analysis of the variables over the period Q-1 1998 to Q-1 2018.

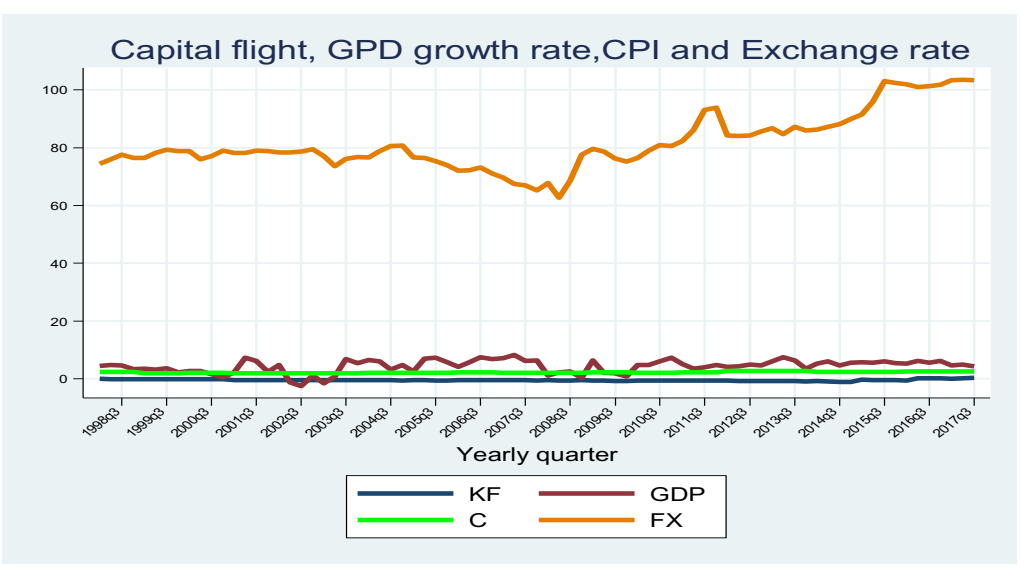

Figure 5: Trend analysis of the variables 
Table 2 shows amounts of capital flight in Kenya over 1998 to 2018.

Table 2: Capital flight in Kenya 1998-2018

\begin{tabular}{llll}
\hline Year & kshs & Year & kshs \\
\hline $\mathbf{1 9 9 8}$ & $-183,183,427.15$ & $\mathbf{2 0 0 9}$ & $-5,057,659,357.81$ \\
\hline $\mathbf{1 9 9 9}$ & $-247,636,027.23$ & $\mathbf{2 0 1 0}$ & $-4,868,731,345.73$ \\
\hline $\mathbf{2 0 0 0}$ & $-587,528,893.18$ & $\mathbf{2 0 1 1}$ & $-5,384,626,830.06$ \\
\hline $\mathbf{2 0 0 1}$ & $-1,461,847,201.35$ & $\mathbf{2 0 1 2}$ & $-6,965,421,091.52$ \\
\hline $\mathbf{2 0 0 2}$ & $-1,515,040,940.10$ & $\mathbf{2 0 1 3}$ & $-7,700,015,579.96$ \\
\hline $\mathbf{2 0 0 3}$ & $-1,777,441,901.22$ & $\mathbf{2 0 1 4}$ & $-9,250,364,167.98$ \\
\hline $\mathbf{2 0 0 4}$ & $-2,046,931,341.89$ & $\mathbf{2 0 1 5}$ & $-4,877,943,247.65$ \\
\hline $\mathbf{2 0 0 5}$ & $-2,383,779,548.24$ & $\mathbf{2 0 1 6}$ & $1,857,007,141.48$ \\
\hline $\mathbf{2 0 0 6}$ & $-3,205,953,486.37$ & $\mathbf{2 0 1 7}$ & $3,527,111,441.42$ \\
\hline $\mathbf{2 0 0 7}$ & $-4,073,416,279.34$ & $\mathbf{2 0 1 8}$ & $4,426,982,562.92$ \\
\hline $\mathbf{2 0 0 8}$ & $-4,472,811,899.14$ & & \\
\hline
\end{tabular}

Source: Owners Computation

\section{Diagnostic Tests}

\section{Tests for multicollinearity}

From the correlation matrix results (Table 3) there exist no significant correlation between any of two the model variables given that no correlation coefficient is more than 0.8 for it to qualify to be a strong correlation (Green, 2012). From the results, all the variables other than GDP growth rate are positively correlated to the capital flight.

Table 3: Correlation coefficients between variables

\begin{tabular}{|c|c|c|c|c|}
\hline & Capital Flight & GDP & Exchange Rate & CPI \\
\hline Capital Flight & 1 & & & \\
\hline \multirow[t]{2}{*}{ GDP } & -0.032 & 1 & & \\
\hline & 0.7767 & & & \\
\hline \multirow[t]{2}{*}{ Exchange Rate } & $0.3188^{* * *}$ & $0.1926^{*}$ & 1 & \\
\hline & 0.0037 & 0.0849 & & \\
\hline \multirow[t]{2}{*}{ CPI } & 0.0696 & $0.3491 * * *$ & $0.6553^{* * *}$ & 1 \\
\hline & 0.5371 & 0.0014 & 0 & \\
\hline
\end{tabular}

Note the $p-$ value for all the test statistics are in parenthesis. Note: $* * *, * *$ denote significance level at $1 \%$, and $5 \%$ \& $10 \%$ respectively

Source: Authors

\section{Tests for stationarity of data}

Unit root tests were conducted to determine the order of integration of the variables prior to the empirical model estimations. This is because estimation of the empirical model without prior knowledge on the order of integration of the variables would lead to spurious regression results. Augmented Dickey - Fuller (ADF) tests and the Phillip - Peron were applied in testing the presence or the absence of unit root in each series. The order of integration is summarized in Table 4

Table 4: Order of integration for variable

\begin{tabular}{llll}
\hline Variable & At level & At first difference & Order of Integration \\
\hline GDP Growth Rate & Stationary & - & $\mathrm{I}(0)$ \\
\hline Exchange rate & Non - stationary & Stationary & $\mathrm{I}(1)$ \\
\hline CPI & Non - stationary & Stationary & $\mathrm{I}(1)$ \\
\hline Capital Flight & Non - stationary & Stationary & $\mathrm{I}(1)$ \\
\hline
\end{tabular}




\section{Optimal number of lags}

The optimal number of lags was determined in order to establish the number of lags that ought to be applied when running the ARDL model. Green (2012) asserted that the lag length selection test could be based on various criteria such as the Schwarz' Bayesian Information Criterion (SBIC), Hannan-Quinn Information Criterion (HQIC), Final Prediction Error (FPE) and Akaike Information Criterion (AIC). The overall results as presented in Table 5 reveal that the optimal number of lags for all variables is one, which is significant at one percent significance level as evidenced by the respective $\mathrm{p}$ - value.

Table 5: Determination of the maximum number of lags for model variables

\begin{tabular}{|c|c|c|c|c|c|c|c|c|c|}
\hline \multicolumn{10}{|c|}{ Selection-order criteria } \\
\hline \multicolumn{5}{|c|}{ Sample: $1999 q 1-2018 q 1$} & \multicolumn{2}{|c|}{ Number of observations } & \multirow[t]{2}{*}{$=$} & \multicolumn{2}{|l|}{77} \\
\hline Lag & $\mathbf{L L}$ & LR & df & p & FPE & AIC & & HQIC & SBIC \\
\hline $\mathbf{0}$ & 0.435 & & & & 17.68 & 11.38 & & 11.42 & 11.47 \\
\hline 1 & -255.80 & $358.7 *$ & 9.00 & 0.000 & $0.211^{*}$ & $6.97^{*}$ & & $7.13 *$ & $7.32 *$ \\
\hline 2 & -252.34 & 6.99 & 9.00 & 0.64 & 0.02 & 7.13 & & 7.35 & 7.74 \\
\hline 3 & -249.85 & 4.98 & 9.00 & 0.84 & 0.29 & 7.27 & & 7.63 & 8.18 \\
\hline 4 & -249.85 & 4.98 & 9.00 & 0.84 & 0.29 & 7.27 & & 7.63 & 8.18 \\
\hline
\end{tabular}

Source: Authors

Therefore, the results for the optimal number of lags imply that when running the ARDL model, one lag is applied for all the variables in the model.

\section{ARDL Model}

\section{Overall Results of the Model}

Table 6 gives the overall results of the model. The effect of the independent and control variables on capital flight was insignificant at all levels of significance levels (1,5 and 10 percent). However previous quarters' capital flight significantly affected current quarter's capital flight. One percent increase in the previous quarters capital flight increases current capital flight by 0.904 ceteris peribus.

From the coefficient of determination $\mathrm{R}$ - square, results indicate that 82.91 percent of all changes in the current quarter's capital flight is determined by previous quarter's capital flight, current quarters and previous quarter's GDP growth rate, exchange rate and corruption. Only 17.01 percent of the total changes in the current quarter's capital flight is determined by the variables outside the model.

Table 6: Overall ARDL Model results

\begin{tabular}{lllllll}
\hline Sample: 1999q3 - 2018q1 & & R-squared & $=$ & 0.8442 & \\
\hline & & Adj R- & squared $=$ & $\mathbf{0 . 8 2 9 1}$ & \\
\hline & Coef. & Std. Err. & $\mathbf{t}$ & $\mathbf{P}>\mathbf{t}$ & [95\% Conf. & Interval] \\
\hline Capital Flight 11. & 0.904 & 0.053 & 17.19 & $0.000^{*}$ & 0.799 & 1.009 \\
\hline Exchange Rate & 0.001 & 0.006 & 0.14 & 0.891 & -0.011 & 0.012 \\
\hline Exchange Rate L1. & 0.003 & 0.006 & 0.55 & 0.584 & -0.009 & 0.016 \\
\hline Gdp growth & 0.003 & 0.008 & 0.43 & 0.67 & -0.012 & 0.019 \\
\hline Gdp growth L1. & 0.001 & 0.008 & 0.18 & 0.855 & -0.014 & 0.017 \\
\hline Corruption & -0.114 & 0.177 & -0.64 & 0.523 & -0.467 & 0.24 \\
\hline Corruption L1. & 0.066 & 0.165 & 0.4 & 0.691 & -0.262 & 0.394 \\
\hline Cons & -0.287 & 0.141 & 2.04 & $0.045^{* *}$ & -0.568 & -0.007 \\
\hline
\end{tabular}

Note: $* * *, * * *$ denote significance level at $1 \%$, and $5 \% \& 10 \%$ respectively

Source: Authors

\section{ARDL Model with Long Run and Short Run Models}

The overall model was decomposed into the long run and short run models in order to determine the relationship between capital fight and the determinants. The results are presented in Table 7. The results indicate that capital flight has a long run relationship with some variables implying that in the long run they move together. First, the results give an evidence for cointegrating model with the coefficient of -0.10 significant at 10 percent significance level. This implies that the short run disequilibrium in the models are 
corrected as a rate of 20 percent quarterly to arrive at the long run stability. Looking at the long run model, results posit that exchange rate have a long run relationship with the capital flight at 10 percent respectively significantly implying that in the end they move together as evidenced by their respective probability values of 0.095 . The short run model upholds the results for the pervious overall ARDL.

Table 7: ARDL model with long run and short run models

\begin{tabular}{lllllll}
\hline & Coef. & Std. Err. & t & P>t & [95\% Conf. & Interval] \\
\hline CDJ & & & & & \\
\hline Capital Flight & -0.1 & 0.05 & -1.83 & $0.071^{*}$ & -0.201 & 0.01 \\
\hline Exchange Rate & Long Run & & & & & \\
\hline GDP Growth Rate & 0.043 & 0.025 & 1.69 & $0.095^{*}$ & -0.008 & 0.094 \\
\hline Corruption & -0.501 & 0.088 & 0.56 & 0.578 & -0.127 & 0.226 \\
\hline Exchange Rate & Short Run & 0.85 & -0.59 & 0.558 & -2.196 & 1.194 \\
\hline GDP Growth Rate & -0.003 & 0.006 & -0.55 & 0.584 & -0.016 & 0.009 \\
\hline Corruption & -0.001 & 0.008 & -0.18 & 0.855 & -0.017 & 0.014 \\
\hline Cons & -0.287 & 0.165 & -0.4 & 0.691 & -0.394 & 0.262 \\
\hline
\end{tabular}

Note: ***,**,*denote significance level at $1 \%$, and $5 \% \& 10 \%$ respectively

Source: Authors

\section{Effect of CPI on Capital Flight}

\section{Correlation analysis between CPI and capital flight}

The correlation analysis results for CPI and capital flight indicated a Spearman's correlation coefficient -0.1557 for CPI. The P values is 0.1650 suggesting that CPI and capital flight were negatively but insignificantly related.

\section{Relationship between CPI and Capital Flight}

The results of the regression analysis extracted from the ARDL model are shown on Table 8 . The coefficients for CPI were -0.114 and 0.066 for previous quarters and -0.501 for CPI in the long run. The $p$ values were 0.523 and 0.691 and 0.558 for CPI respectively. The results indicated that the previous quarters CPI is positively related to capital flight though not significantly, since the $p$ values are not less than 0.1 . The current quarters CPI and CPI in the long run however were negatively related to capital flight but not significantly.

Table 8: Relationship between CPI and Capital Flight

\begin{tabular}{lllllll}
\hline & Coefficient & Std. Errors. & t-statistic & $\mathrm{P}>\mathrm{t}$ & {$[95 \%$ Conf. } & Interval $]$ \\
\hline CPI & -0.114 & 0.177 & -0.640 & 0.523 & -0.467 & 0.240 \\
\hline CPI (-1) & 0.066 & 0.165 & 0.400 & 0.691 & -0.262 & 0.039 \\
\hline$\underline{\text { Long run }}$ & & & & & & \\
\hline CPI & -0.501 & 0.850 & -0.590 & 0.558 & -2.196 & 1.194 \\
\hline
\end{tabular}

Note: $* * *, * *, *$ denote significance level at $1 \%, 5 \%$ and $10 \%$ respectively

Source: Authors

\section{Hypothesis testing}

The null hypothesis would be rejected if the $\mathrm{p}$ value was less than or equal to $0.1,0.05$ and 0.01 . The $\mathrm{p}$ values were for CPI in the short run and CPI in the long run.0.523, 0.691 and 0.558 respectively. They were not less than 0.05 . The null hypothesis was not rejected. The conclusion therefore was that CPI had no significant relationship with capital flight.

\section{Effect of GDP growth rate on Capital Flight}

\section{Correlation between GDP growth rate and Capital Flight}

The correlation analysis results for GDP growth rate and capital flight indicated a Spearman's correlation coefficient of -0.0575 with a $\mathrm{P}$ value of 0.6104 . This denoted that, GDP growth rate and capital flight had a negative but insignificant relationship since the $\mathrm{P}$ value was not less 0.05 . 


\section{Relationship between GDP growth rate and Capital Flight}

The regression results between GDP growth rate and capital flight shows correlation coefficient of 0.01 and 0.003 for GDP growth rate in the short run, and 0.049 for GDP growth rate in the long run (Table 9). The results were extracted from the ARDL models. This indicated that capital flight and GDP growth rate had a positive relationship both in the short and long run. The $p$ values were $0.670,0.855$ and 0.578 respectively meaning that quarterly GDP growth rate and capital flight had an insignificant association both in the short run and in the long run.

Table 9: Regression results for GDP growth rate and capital flight

\begin{tabular}{lllllll}
\hline Short run & Coeff. & Std Errors & $\mathrm{t}$ & $\mathrm{p}>\mathrm{t}$ & $95 \%$ & conf. \\
\hline GDP & 0.003 & 0.008 & 0.43 & 0.67 & -0.012 & 0.019 \\
\hline GDP & 0.001 & 0.008 & 0.18 & 0.855 & -0.014 & 0.017 \\
\hline Long Run & & & & & -0.127 \\
\hline GDP & 0.049 & 0.088 & 0.56 & 0.578 & & 0.226 \\
\hline
\end{tabular}

Note: $* * * * *, *$ denote significance level at $1 \%, 5 \%$ and $10 \%$ respectively

Source: Authors

\section{Hypothesis testing}

The null hypothesis will be rejected if the $p$ value was less than and equal to $0.1,0.05$ and 0.01 . The $p$ values were 0.670 and 0.855 GDP growth rate the short run and 0.578 for the long run respectively. The $\mathrm{p}$ values are not less than 0.05 or .10 . The null hypothesis was therefore not rejected. In conclusion, GDP growth rate and capital flight had no significant association both in the short run and in the long run.

\section{Effect of Exchange Rate on Capital Flight}

\section{Correlation between Exchange Rate on Capital Flight}

The correlation analysis results for exchange rate and capital flight indicated a Spearman's correlation coefficient of -0.0289 with a $\mathrm{P}$ value of 0.7977 . This meant that exchange rate and capital flight had a negative and statistically insignificant relationship since the $\mathrm{P}$ value was not less 0.05 .

\section{Relationship between Exchange Rate on Capital flight}

The regression analysis results extracted from the ARDL models between capital flight and exchange rate are shown on Table 10. The coefficients were 0.002 and 0.003 for exchange rate in the short run, 0.43 for exchange rate for long run. This meant that exchange rate had a positive relationship with capital flight both the short run and long run. The p values were 0.891 and 0.584 and 0.095 respectively. This signified that exchange rate and capital flight had positive and statistically insignificant relationship with capital flight in the short run. However, in the long run the $\mathrm{p}$ value of 0.095 signified that the relationship was statistically significant at $10 \%$ level of significant in the long run. A one \% increase in exchange rate would lead to a $0.043 \%$ increase in capital flight.

Table 10: Regression results for exchange rate on capital flight

\begin{tabular}{lllllll}
\hline Short run & Coeff. & Std Errors & $\mathrm{t}$ & $\mathrm{p}>\mathrm{t}$ & $95 \%$ & conf. \\
\hline Exchange rate & 0.001 & 0.006 & 0.14 & 0.891 & -0.011 & 0.012 \\
\hline Exchange rate 11 & 0.003 & 0.006 & 0.55 & 0.584 & -0.009 & 0.016 \\
\hline Long Run & & & & & & 0.094 \\
\hline Exchange rate & 0.043 & 0.025 & 1.69 & $0.095^{*}$ & 0.008 & 0.094 \\
\hline
\end{tabular}

Note: $* * *, * *, *$ denote significance level at $1 \%, 5 \% \& 10 \%$ and respectively Source: Authors

\section{Hypothesis Testing}

The null hypothesis will be rejected if the $p$ value was less than and equal to $0.1,0.05$ and 0.01 . The $p$ values are 0.891 and 0.584 for exchange rate in the short run. The $\mathrm{p}$ values are not less than 0.05 and 0.1 therefore the null hypothesis not rejected and was adopted. On the other hand, the $\mathrm{p}$ value for exchange rate in the long run was 0.095 . This was less than 0.1 and the null hypothesis was rejected and alternate adopted. In conclusion, exchange rate had a significant and positive association with capital flight in the long run. 


\section{Other findings: Effect of Lagged Capital Flight on Capital Flight}

\section{Relationship between lagged capital flight and capital flight}

Table 11 showed the regression results of previous quarter's capital flight on capital flight. The coefficient was 0.904 . This indicated that capital flight had a positive relationship with lagged capital flight. The $\mathrm{p}$ value was 0.000 meaning that the relationship was statistically significant. A one $\%$ increase in previous quarter's capital flight would lead to a $0.904 \%$ increase in capital flight.

Table 11: Regression results for lagged capital flight on capital flight

\begin{tabular}{|c|c|c|c|c|c|}
\hline$\underline{\text { Short run }}$ & Coefficient & Std. Errors. & t-statistic & $\mathrm{P}>\mathrm{t}$ & [95\% Conf. \\
\hline Capital Flight 11. & 0.904 & 0.053 & 17.190 & $0.000 * * *$ & 1.009 \\
\hline
\end{tabular}

Note: $* * *, * *, *$ denote significance level at $1 \%, 5 \% \& 10 \%$ and respectively

Source: Authors

\section{Results and discussions}

The first research objective was to determine the relationship between corruption and capita flight. The null hypothesis was not rejected.The results therefore indicated that CPI and capital flight did not have a significant relationship. The main explanation for the insignificant influence could be due to the fact that the fight against corruption in Kenya is bearing some fruit. Latest statistics from TIs CPI demonstrates that the situation on fighting corruption is getting better. Kenya ranked 143 out of 180 countries compared to its ranking in 2016 which was 145. Kenya's CPI score also improved in 2017 to a score of 28 from the preceding 26. In SSA Kenya ranked 28 out of the 49 nations that were surveyed. Kenya was also below the SSA regional average of 32 . A higher score in the index echoes less corruption and improved measures to prevent corruption findings that CPI and capital flight had no significant relationship was consistent with findings reported by Wujung and Mbella (2016). The findings were also not consistent with the political economy theory that supports a positive relationship between CPI and capital flight. The findings were also inconsistent with the theory of Capital flight which argues that under situations of poor governance and bad institutional quality corrupt public authorities take advantage to hoard personal wealth overseas. Several studies have also given inconsistent findings from our study findings and they include, studies by Domfeh et al. (2018), Orkoh, Claassen and Blaauw (2018); Abotsi (2018) and Trabelsi, Kharrat and Feki (2018) which reported positive relationship and Asongu and Nwachukwu (2016) who found a negative relationship.

The second research objective was to determine the relationship between GDP growth rate and capital flight. The null hypothesis was not rejected. The results indicated that GDP growth rate did not affect capital flight in Kenya in the period of study. The findings were consistent with findings by Domfeh et al. (2018) and Uddin, Yousuf and Islam (2017 who reported that GDP had no significant relationship with capital flight. The findings however were inconsistent with several studies carried out by Forson et al. (2017) and Bekele (2017) who reported a negative association and Salandy and Henry (2018) and Pradhan and Gourishankar (2017) who reported a positive relationship.

The third research objective was to determine the relationship between real exchange rate and capital flight. The null hypothesis was rejected and this indicated that exchange rate and capital flight had a positive long run significant relationship. This finding implied that capital flight was sensitive to currency depreciation. Future expectations of a deterioration in real exchange rates would alert capital owners to the likelihoods of impending currency depreciation and prompt them to send their capital abroad. The findings were consistent the theory of Capital flight. The findings were consistent with findings by Pradhan and Gourishankar (2017); Cheung et al. (2016) and Ahmad and Sahto (2016) but inconsistent with study by Egbe (2015) whose results showed that capital flight and real exchange rate had no significant relationship.

Results disclosed that the relationship between lag of capital flight and current values of capital flight was positive and statistically significant at 0.01 level in the short-run. This indicated that there was a tendency for hysteria in events of capital flight. This result was in line with the studies by (Al-Fayoumi et al., 2012; Geda and Yimer, 2015; Ndikumana and Boyce, 2008; Nyoni, 2000 and Forson et al., 2017). Collier, Hoeffler, and Pattillo (2001).

\section{Conclusions}

The findings of the study were that corruption did not have a significant relationship with capital flight. This implies that Government should intensify its fight on corruption as it seems to be bearing fruit. All institutions charged with fighting corruption should continue fighting corruption. All key law enforcement agencies such as Ethics and Anti Corruption Commission needs to fight corruption in order to encourage capital inflows as opposed to capital flight. This study provides a contribution by providing evidence that Exchange rate and capital flight had a positive statistically significant long run association. Central Bank of Kenya should adopt the foreign exchange system that keep the value of the country's currency as realistic as possible. The macroeconomic policies should anchor the exchange rate volatilities and build more foreign reserves to stabilize the exchange rate. The findings of the study were that GDP growth rate did not have a significant relationship with capital flight. Central Bank of Kenya should implements sound macroeconomic policies, which stimulate economic growth since, increase in economic growth reduces capital flight and when 
combined with the other variables; they have a joint effect on the level of capital flight. The results also indicated that there was a short run relationship between lagged capital flight and current values of capital flight, which was positive and statistically significant. This research therefore, provides input to regulators showing that it would be necessary to devise policies that would prevent further capital flight and generate capital flight reversal e.g. repatriation of flight capital to enhance the growth initiatives with indiscriminate controls on capital outflow. The government also needs to enact a law-protecting Kenyans involved in capital flight to enable them repatriate this stolen money back home which would indirectly go a long way to reduce unemployment and improve the living standards of the citizens. The study used the World Bank method of measuring capital flight, it is expected that further research could use different measures of capital flight and compare the analysis of results to each other.

\section{References}

Abalkin, A. and Whalley, J. (2002). The Problem of Capital Flight from Russia. The World Economy. 22(3), 421-444 https://doi.org/10.1111/1467-9701.00209

Abotsi, A.K. (2018). Influence of Governance Indicators on Illicit Financial Outflow from Developing Countries. Contemporary Economics, 12 (2), 139-152 https:// doi.org /10.5709/ce.1897-9254.268

Ahmad, B. and Sahto, Q.D. (2016). Determinants of capital flight in Pakistan. IBT Journal of Business Studies, 11(2), 55-64.

Ajayi, I.S. (2007). Dynamics of capital flight: Causes and determinants. Paper prepared for the Senior Policy Seminar on Capital Flight from Sub-Saharan Africa: Implications for Macroeconomic Management and Growth, Pretoria, South Africa, 30 October to 2 November 2007.

Alam, M. I. and Quazi, R. M. (2003). Determinants of capital flight: An econometric case study of Bangladesh. International Review of Applied Economics, 17(1), 085-103. https:// doi.org /10.1080/713673164

Alesina, A. and Tabellini, G. (1989). External Debt, Capital Flight, and Political Risk. Journal of International Economics, 27(3/4), 199-220. https:// doi.org 10.1016/0022-1996(89)90052-4

Al-Fayoumi, N., Alzoubi, M. and Abuzayed, B. (2011). The Determinants of Capital Flight: Evidence from MENA Countries. International Business and Economic Research Journal, 11, 1-10. https://doi.org/10.19030/iber.v11i1.6666

Ali, A. and B. Walters (2011). On the Causes of Capital Flight from Sub-Saharan Africa. University of Manchester Working Papers.

Asongu, S.and Nwachukwu, J. (2016). Fighting Capital Flight in Africa: Evidence from Bundling and Unbundling Governance. AGDI Working Paper, No. WP/16/047

Barasa, T. (2018). Illicit Financial Flows in Kenya: Mapping of the Literature and Synthesis of the Evidence. www.pasgr.org/wpcontent/uploads/2018/.../Kenya-Illicit-Financial-Flows-Report.pdf

Boyce, J. K. and Ndikumana, L. (2001). Is Africa a net creditor? New estimates of capital flight from severely indebted sub-Saharan African countries, 1970-1996. Journal of Development Studies, 38(2), 27-56.

Cerra, V., M. Rishi and Saxena, S.C. (2008). Robbing the riches: Capital flight, institutions, and debt. Journal of Development Studies, 44 (8), 1190-213 https://doi.org/10.1080/00220380802242453.

Cheung, Y.W., Steinkamp, S. and Westermann, F. (2016). China's Capital Flight: Pre-and Post-Crisis Experiences Journal of International Money and Finance, 66, 88-112 https://doi.org/10.1016/j.jimonfin.2015.12.009

Collier, P., Hoeffler, A. and Patillo, C. (2004). Africa's Exodus: Capital Flight and the Brain Drain as Portfolio Decisions. Journal of African Economies, 13, 15-54.

Creswell, J. W., Plano Clark, V. L., Gutmann, M and Hanson, W. (2003). Advanced mixed methods research designs. In Handbook on mixed methods in the behavioral and social sciences, ed. A. Tashakkori and C. Teddlie, 209-40. Thousand Oaks, CA: Sage.

Deppler, M. and Williamson, M. (1987). Capital flight: Concepts, measurement and Issues. Staff Studies for the World Economic Outlook. Washington, DC: The International Monetary Fund.

Domfeh, K. O, Osei-Assibey, E. and Michael, D. (2018). Corruption, institutions and capital flight: evidence from Sub-Saharan Africa. Journal of Economic Studies, 45 (1),59-76 https://doi.org/10.1108/JES-10-2016-0212

Egbe, O. J. (2015). A Dynamic Analysis of the Impact of Capital Flight on Real Exchange Rate in Nigeria. IOSR Journal of Economics and Finance, 6 (1), 2321-5933

Epstein, G.A. (2005). Capital Flight and Capital Controls in Developing Countries. Northampton: Edward Elgar.

Erbe, S. (1985). The Flight of Capital from Developing Countries. Inter economics, 268-275 https://doi.org/10.1007/BF02925467

Fiol, C. M., and O'Connor, E.J (2003). Waking Up! Mindfulness in the Face of Bandwagons, Academy of Management Review, 28, 54-70 https://doi.org/10.5465/AMR.2003.8925227

Fofack, H. and Ndikumana, L. (2010). Capital Flight Repatriation: Investigation of its Potential Gains for Sub-Saharan African Countries. African Development Review, 22(1), 4-22. https://doi.org 10.1111/j.1467-8268.2009.00226.x

Forson, R., Obeng, K.C, and Brafu-Insaidoo, W. (2017), Determinants of Capital Flight in Ghana (2017). Journal of Business and Enterprise Development; Vol. 7, PP 151-180

Gachoki, C. and Nyang 'oro, O. ( 2016). Impact of Capital Flight on Private Investment in Kenya. International Journal of Economics, 1 (2), 1 - 15.

Geda, A. and Yimer, A. (2016). Capital Flight and its Determinants: The Case of Ethiopia. African Development Review, 28 (S1), 39-49. https://doi.org 10.1111/1467-8268.12180

Greene, W. H. (2012, Econometric Analysis, Prentice Hall. 7th ed. 
Gusarova, V. (2009). The impact of Capital flight on economic growth. Unpublished Master's Thesis of the KYIV School of 'Economics.

Hasnul, A. G. and Masih, M. (2016). Role of instability in affecting capital flight.Magnitude: An ARDL bounds testing approach. Paper No. 72086, M P R A, Paper No. 72086.

Heggstad, K. and Fjeldstad, O.H. (2010). How banks assist capital flight from Africa: A literature review. Technical report, The Norwegian Agency for Development Cooperation (NORAD).

Hermes, N., Lensink, R. and Murinde, V. (2002). Capital flight, policy uncertainty, and the instability of the international financial system. In A. Mullineux and V. Murinde, eds., Handbook of International Banking. Cheltenham: Edward Elgar (forthcoming) IMF.

Hope, K.R, (2014). Kenya's corruption problem: causes and consequences, Commonwealth \& Comparative Politics, 52:4, $493-512$. https://doi.org 10.1080/14662043.2014.955981

Kar, D. and Cartwright-Smith, D. (2008). Illicit financial flows from developing countries: 2002-2006. Technical report, Global Financial Integrity (GFI).

Kar, D. and Cartwright-Smith, D. (2010). Illicit Financial Flows from Africa: Hidden Resource for Development. Washington, DC: Global Financial Integrity.

Kar, D and Spanjers, J. (2014). Illicit Financial Flows from Developing Countries: 2003-2012. Global Financial Integrity. Retrieved from www. gfintegrity. Org.

Kindleberger, C. P. (1987). A Historical Perspective,in: Donald R. Lessard, and John Williamson (eds.), Capital Flight and Third World Debt, Washington DC, Institute for International Economics, 7-26.

Kipyegon, L. (2004). Determinants of capital flight from kenya. Unpublised masters thesis. Kenyatta University.

Kimenyi, S.M., Mwega, F.M and Ndung'u, S.N. (2016) African Lions: Kenya country case study: United Nations University-World Institute for Development Economics Research (UNU-WIDER), the University of Cape Town's Development Policy Research Unit (DPRU)

Le, Q. V. and Rishi, M. (2006). Corruption and capital flight: An empirical assessment. International Economic Journal, 20(4), 523540. https://doi.org/10.1080/10168730601027161

Letete, E. M. (2015). Essays on Institutions and Economic Development in Kenya: Degree of Doctor of Philosophy Thesis. University of Cape Town.

Letete, E. and Sarr, M. (2017). Illicit Financial Flows and Political Institutions in Kenya, Working Paper Series $\mathrm{N}^{\circ} 275$, African Development Bank, Abidjan, Côte d'Ivoire.

Liew, S.L. (2016). Review on Determinants of Capital Flight Review on Determinants of Capital Flight. M P A. Retrieved from https://mpra.ub.uni-muenchen.de/70445/

Lucas, R. E. (1990). Why Doesn't Capital Flow from Rich to Poor Countries? American Economic Review, 80 (2), $92-9$

Moeva, Z. S.A. (2007). Determinants of Capital Flight in Kenya (1987-2007). Unpublished Master thesis, University of Nairobi

Moulemvo, A. (2016). Impact of Capital Flight on Public Social Expenditure inCongo-Brazzaville. African Development Review, 28 (S1),113-123. https://doi.org/10.1111/1467-8268.12185

Mpenya, A.H.T., Metseyem, C. and Epo, B.N. (2016). Natural resources and capital flight in Cameroon. African Development Review 28(S1):88-99. https://doi.org/10.1111/1467-8268.12183

Muchai, D. N., and Muchai, J. (2016). Fiscal Policy and Capital Flight in Keny. African Development Review. 28( S1), 8-21.

Mudida, R. (2011). Empirical Aspects Of Capital Flight in Kenya, 1970-2009. Nairobi: Navarra Center for International Development Working Paper $\mathrm{N}^{\circ} 08 / 2011$.

Ndiaye, A.S. (2011). Capital Flight and its Determinants in the Franc Zone. AERC Research Paper No.215. African Economic Research Consortium, Nairobi.

Ndiaye, A.S. (2014). Is Capital Flight Decisive in Explaining Economic Growth Performance in the AfricanFranc Zone?” GDN 15 TH Annual Global Development Conference on Structural Transformation in Africa and Beyond. 18-20 June 2014, Accra, Ghana.

Ndikumana, L.and Boyce, J. K. (2003). Public debts and private assets: Explaining capital flight from Sub- Saharan African countries. World Development. 31 (1): 107-130.

Ndikumana, L. and Boyce, J. K. (2008). New Estimates of Capital Flight from Sub-Saharan African Countries: Linkages with External Borrowing and Policy Options. PERI/UMass, Working Paper 166.

Ndikumana, L. and Boyce, J. K. (2011). Capital Flight from sub-Saharan African Countries: Linkages with

External Borrowing and Policy Options. International Review of Applied Economics, 25 (2), 149-170. https://doi.org/10.1080/02692171.2010.483468

Ndikumana, L. and Boyce, J. K. (2012). Capital Flight from North African Countries. PERI Research Report. Amherst, MA: Political Economy Research Institute

Ndikumana, L. and Sarr, M. (2016). Capital flight and Foreign direct investment in Africa: An Investigation of the role of natural resource endowment. WIDER Working Paper 2016/58.

Ndikumana, L. and Boyce, J. K. (2018). Capital Flight from Africa: Updated Methodology and New Estimates PERI/UMass, Working Paper. 
Nkurunziza, D. J. (2012). Illicit Financial Flows: A Constraint on Poverty Reduction in Africa. Association of Concerned Africa. Scholars Bulletin, 87, 15-21.

Nkurunziza, J. D. (2015). Capital Flight and Poverty Reduction in Africa, in I. Ajayi and L.

Ndikumana (eds.), Capital Flight from Africa: Causes, Effects and Policy Issues (pp. 81-110), Oxford University Press, Oxford.

Ng'eno, N.K. (2000). Capital Flight in Kenya. In: Ajayi, I. and Khan, M. (eds). External Debt and Capital Flight in Sub-Saharan Africa. Washington, D.C.: The IMF Institute., 300- 321.

Olawale, O. O. and Ifedayo, M. O. (2015). Impacts of Capital Flight on Economic Growth in Nigeria. International Journal for Innovation Education and Research.3 (8)

Onodugo, V. A., Kalu, I. E., Anowor, O. F., and Ukweni, N. O. (2014). Is Capital Flight Healthy for Nigerian Economic Growth? An Econometric Investigation. Journal of Empirical Economics, 3(1), 10-24.

Pradhan, A.K and Gourishankar, S.H. (2017). The Capital Flight from India: A Case Of Missing Woods for Trees. The Singapore Economic Review, 62, 2. https://doi.org/10.1142/S0217590816500429

Salandy, M. and Henry, 1. (2018). Determinants of Capital Flight from Beautiful Places: The Case of Small Open Economy of Trinidad and Tobago, The Journal of Developing Areas, 52(4) DOI https://doi.org/10.5897/JEIF2017.0847.

Scharfstein, D. S, and Jeremy C, S. (1990). Herd Behaviour and Investment. Amercian Economic Review, 80, $465-479$. https://doi.org/10.1.1.184.4434\& \& \& \& rep=replype $=p d f$

Smith, A. (1976). An Inquiry into the Nature and Causes of the Wealth of Nations, ed. by RH. Campbell and AS. Skinner, 2 vol. (Oxford: Clarendon Press).

Tashakkori, A. and Teddlie. C. (1998). Mixed methodology: Combining qualitative and quantitative approaches. Applied Social Research Methods Series, vol. 46. Thousand Oaks, CA:Sage.

Transparency International, (2016). Corruption Perceptions Index 2016. Retrieved from https://www.transparency.org/news/feature/corruption_perceptions_index_2016

Trabelsi, M.A., Kharrat, O., Feki, R. (2018). The Root Causes of Capital Flight in Tunisia: An Empirical Investigation. International Journal of Social Science and Economic Research, 3, (9).

Uddin, M. J., Yousuf, M. and Islam, R. (2017). Capital flight affecting determinants in Bangladesh: An Econometric Estimation. International Journal of Economics, Commerce and Management 8. Sage

Waris, A. and Fröberg, K. F. (2011). Bringing the billions back How Africa and Europe can end illicit capital flight. Stockholm: Forum Syd förlag.

Wujung, V. A., and Mbella, E. (2016). Capital Flight and Economic Development: The Experience of Cameroon. Economics, 5(5), 64-72. https://doi.org /10.11648/j.eco.20160505.11 